УДК 347.7(477)

DOI https://doi.org/10.32837/pyuv.v0i5(34).649

\author{
I. I. Сядриста \\ orcid.org/0000-0002-4340-3593 \\ кандидат юридичних наук, доцент, \\ доцент кафедри правового забезпечення господарської діяльності \\ Харківського національного університету внутрішніх справ
}

\title{
ОЗНАКИ ПОНЯТТЯ «АКЦІОНЕРНА ВІДПОВІДАЛЬНІСТЬ»
}

Говорячи про відповідальність в акціонерних правовідносинах $з$ огляду на їі сутність та ознаки, можна констатувати, що вона носить цивільно-правовий характер, оскільки окреслені відносини є приватними, майново-організаційними, ïx учасники є рівними під час реалізації ними своїх корпоративних прав та виконання покладених на них обов'язків. Норми цивільного законодавства здійснюють лише загальне регулювання положень стосовно відповідальності учасників акціонерних правовідносин, таким чином, акціонерна відповідальність є різновидом цивільної відповідальності, а отже, характеризується всіма загальними ознаками останньої. При цьому специфічність правової природи відповідних правовідносин, покликаних на забезпечення балансу інтересів акціонерного товариства (далі - AT) та його акціонерів, вимагає спеціального правового регулювання особливостей відповідальності відповідних суб'єктів через їі характерні ознаки.

Метою написання статті є з'ясування загальних та спеціальних ознак відповідальності учасників акціонерних правовідносин.

Особливості акціонерних відносин та певних правових зв'язків, що існують між їхніми суб'єктами, вимагають їх конкретизації, спеціального, відмінного від існуючих підходів до різновиду цивільних правовідносин правового регулювання. Це стає можливим лише із зовсім інших позицій корпоративного права [1, с. 217]. 3 урахуванням зазначеного можна стверджувати, що акціонерній відповідальності властиві певні ознаки, які у свою чергу можна поділити на загальні (характерні як цивільно-правовій відповідальності, так і відповідальності учасників акціонерних правовідносин) та спеціальні (характерні виключно відповідальності учасників акціонерних правовідносин). До загальних ознак можна віднести такі.

По-перше, відповідальність учасників акціонерних правовідносин має захисний, відновлювальний, компенсаційний (майновий), а не каральний характер. Основною метою відповідальності учасників акціонерних правовідносин $€$ відновлення порушеного суб'єктивного права. Досягнення цієї мети є можливим лише в разі застосування таких заходів відповідальності, які носять майновий характер, оскільки всі права учасників, навіть немайнові, опосередковано пов'язані з майном. Зокрема, право акціонера на участь в управлінні АТ має для акціонера особливе значення не саме по собі, а через можливість визначення діяльності товариства та отримання зрештою більшого прибутку. Те саме стосується і права на інформацію, оскільки акціонера цікавлять напрями його інвестицій, організація та результати інвестиційного процесу стосовно його капіталу. У зв'язку з тим, що в акціонерних правовідносинах шкода завжди зумовлює виникнення майнових прав, а відповідальність зумовлює повне відшкодування завданих збитків (ч. 1 ст. 22 Цивільного кодексу України (далі - ЦК України) [2]), то, відповідно, головну роль в таких правовідносинах відіграватиме компенсаційний, відновлювальний характер відповідальності.

По-друге, відповідальність учасників акціонерних правовідносин може покладатися на спадкоємців. Актами цивільного законодавства встановлено загальне правило, відповідно до якого до складу спадщини входять усі права та обов'язки, що належали спадкодавцеві на момент відкриття спадщини і не були припинені внаслідок його смерті (ч. 1 ст. 1218). Говорячи про спадкування в корпоративних правовідносинах, необхідно зазначити, що до спадкоємців частки в статутному капіталі АТ переходить право власності на акції спадкодавця, а разом із ними - всі права, обов'язки та відповідальність за їх невиконання. Зокрема, Постановою Пленуму Верховного Суду України № 7 від 30.05 .2008 р. «Про судову практику у справах про спадкування" [3] встановлено, що спадкується не право на участь, а право на частку в статутному капіталі товариства, якщо інше не встановлено установчими документами товариства.

По-третє, відповідальність до учасників акціонерних правовідносин може застосовуватися як у судовому, так і в позасудовому порядку. У приватноправових відносинах сторони мають право самостійно, без втручання державних органів, регулювати відносини, що між ними виникають, у т. ч. передбачати відповідальність (у договорах, установчих документах юридичних осіб). Так, наприклад, особа, що неналежним чином виконала свої договірні зобов'язання, без втручання державних органів може відшкодувати завдані 
збитки, тобто понести юридичну відповідальність у вигляді виконання додаткових обов'язків. Порядок застосування відповідальності до учасників акціонерних правовідносин може встановлюватися внутрішніми локальними актами, що регулюватимуть порядок подачі та розгляду заяв.

По-четверте, учасники акціонерних правовідносин несуть відповідальність як солідарні боржники. Згідно з ч. 4 ст. 92 ЦК України, члени органу юридичної особи несуть солідарну відповідальність за збитки, завдані ними юридичній особі. Ст. 543 ЦК України передбачає, що в разі солідарного обов' язку боржників кредитор має право вимагати виконання обов'язку частково або в повному обсязі як від усіх боржників разом, так і від будь-кого з них окремо. Кредитор, який одержав виконання обов'язку не в повному обсязі від одного із солідарних боржників, має право вимагати недоодержане від решти солідарних боржників. Солідарні боржники залишаються зобов'язаними доти, доки їхній обов'язок не буде виконаний у повному обсязі. Таким чином, якщо спільними діями або бездіяльністю учасників акціонерних правовідносин спричиняється шкода іншим учасникам зазначених відносин, то вони несуть відповідальність як солідарні боржники.

Особливий характер призначення та способів реалізації відповідальності учасників акціонерних правовідносин визначає спеціальні ознаки останньої, до яких можна віднести такі:

1) акціонерна відповідальність може застосовуватися виключно до учасників акціонерних правовідносин, вона тісно пов'язана з акціонерними правовідносинами, поширює свою дію на їх учасників, забезпечує виконання покладених на них обов'язків [4, с. 184]. Акціонерні правовідносини загалом мають регулятивний характер, вони виникають як правовий зв'язок між учасниками окреслених правовідносин з метою реалізації прав і обов'язків останніми та регулюються нормами законодавства, статутом, акціонерним договором. Порушення відповідних норм законодавства, статуту, акціонерного договору та відповідного суб'єктивного права або охоронюваного інтересу учасників акціонерних правовідносин є юридичними фактами, на підставі яких виникають охоронні відносини між особою, чиї права або законні інтереси порушено, та особою - правопорушником;

2) підставою застосування акціонерної відповідальності $€$ невиконання або неналежне виконання обов'язків учасниками акціонерних правовідносин, а також порушення прав та законних інтересів інших учасників окреслених відносин. Згідно зі ст. ст. 610, 623 ЦК України в разі невиконання або неналежного виконання зобов'язання боржником він зобов'язаний відшкодувати кредиторові завдані збитки. Говорячи про обов'язки як підставу настання відповідальності, необхідно зазначити, що в Законі України «Про акціонерні товариства» [5] відсутній перелік обов'язків АТ, у зв'язку з чим важко визначитися, за що саме товариство як учасник акціонерних правовідносин повинно нести відповідальність. Актуальним залишається питання і щодо обов'язків акціонерів, незважаючи на те, що вони визначені законодавством (ст. 29 Закону України «Про акціонерні товариства»), однак науковці, характеризуючи дану категорію, акцентують увагу на неможливості застосування відповідальності до акціонерів за їх невиконання та й взагалі ставиться під сумнів існування окреслених у законі обов'язків [6, с. 142-144]. Отже, відповідальність до учасників акціонерних правовідносин може застосовуватися виключно за невиконання або неналежне виконання покладених на них обов'язків та за порушення прав, законних інтересів інших учасників окресленого правового зв'язку. Наприклад, згідно зі ст. 25 Закону України «Про акціонерні товариства» кожною простою акцією товариства їі власнику - акціонеру надається однакова сукупність прав, включаючи право на участь в управлінні. У разі невиконання покладеного на АТ обов'язку щодо проведення чергових загальних зборів відповідно до ст. 32 Закону України «Про акціонерні товариства» в акціонерів має виникати право вимоги проведення позачергових загальних зборів та відповідний обов'язок у товариства їх провести;

3) відповідальність учасників акціонерних правовідносин носить ініціативний характер іï застосування. Підставою застосування відповідальності до учасників акціонерних правовідносин є виключно волевиявлення учасників (добровільне виконання особою, яка не виконала зобов' язання, свого обов'язку) або вимоги особи, чиї права та законні інтереси порушені, щодо примусового застосування заходів відповідальності. Отже, актуальним є питання про можливість захисту прав та законних інтересів товариства, коли вони порушуються його законними представниками, які повинні захищати та представляти інтереси останнього. Відповідно до ст. 92 ЦК України юридичні особи набувають відповідних прав та обов'язків через свої органи. Судова практика, зокрема п. 11 Постанови Пленуму Верховного Суду України від 24.10.2008 р. № 13 «Про практику розгляду судами корпоративних спорів» [7], не передбачає право акціонерів звертатися до суду за захистом прав та інтересів інших акціонерів та самого товариства поза відносинами представництва, а також обгрунтовувати свої вимоги порушенням прав інших акціонерів. Вирішуючи спір по суті, господарський суд повинен установити наявність в особи, яка звернулася з позовом, суб'єктивного матеріального права або законного інтересу, на захист якого подано позов, а також з'ясувати 
наявність чи відсутність факту їх порушення або оспорювання. Зокрема, не можуть бути також задоволені вимоги щодо захисту права, яке може бути порушено в майбутньому і щодо якого невідомо, чи буде воно порушено;

4) відповідальність учасників акціонерних правовідносин - це обтяження у вигляді обов'язку, як наслідку невиконання або неналежного виконання зобов'язань та порушення прав, законних інтересів інших учасників. У сфері акціонерних відносин його сформульовано в санкції правової норми або в статуті чи акціонерному договорі -у тих його пунктах, де передбачено наслідки невиконання або неналежного виконання договірного зобов'язання. Наприклад, акціонери, яким належать привілейовані акції, мають право отримувати дивіденди навіть у разі відсутності або недостатності чистого прибутку (п. 2 ч. 2 ст. 30 Закону України «Про акціонерні товариства»). У разі виконання АТ свого обов' язку з виплати дивідендів належним чином у жодному разі не може йтися про відповідальність. Якщо ж АТ відмовляється виконати покладений на нього обов'язок (у випадку нескликання або несвоєчасного скликання загальних зборів чи невключення відповідного питання до порядку денного), то, відповідно, у таких акціонерів виникає право вимоги прийняття рішення загальними зборами про виплату дивідендів, а у товариства виникає обов'язок, що існує вже в охоронних відносинах, прийняти відповідне рішення, що й вважатиметься відповідальністю за невиконання або неналежне виконання покладеного обов' язку;

5) підстави, вид та розмір відповідальності, що можуть застосовуватися до учасників акціонерних правовідносин, встановлюються як нормами законодавства, так і спеціальними внутрішніми локальними актами, в яких можуть деталізуватися санкції, передбачені законодавством, або встановлюватися власні самостійні санкції, якщо останні не передбачені нормами чинного законодавства, задля підвищення ефективності роботи товариства та захисту прав i законних інтересів учасників акціонерних правовідносин. Законодавство дозволяє сторонам урегулювати свої відносини певним чином, відмінним від загальних приписів, тобто сторонам надається право на саморегулювання. Але саморегулювання відповідальності може здійснюватися лише в межах, визначених законом. Зокрема, статут АТ може передбачати можливість укладення між акціонерами акціонерного договору, за яким на акціонерів покладається додатковий обов'язок брати участь у загальних зборах (ст. 29 Закону України «Про акціонерні товариства») та, відповідно, передбачатися відповідальність за невиконання покладеного обов'язку. Потреба в локальних корпоративних нормах або доцільність їх прийняття виникають із підстав: уточнення та конкретизації норм законів, установлення механізмів їх реалізації; запровадження інших моделей регулювання корпоративних відносин порівняно з передбаченими в законі, наскільки це припускається законом, або в них фіксується вибір однієї з альтернативних моделей; заповнення прогалин у законодавстві; внаслідок спеціальних приписів законодавства про передання тих чи інших питань до компетенції недержавних організацій - для їх належного здійснення, що потребує відповідного регулювання [8, с. 153].

Враховуючи вищенаведене, можна зробити висновок, що акціонерну відповідальність можна розглядати як обов'язок учасника акціонерних правовідносин зазнати певних санкцій. Особливістю акціонерної відповідальності є ініціативний характер її застосування. Підставою її реалізації є невиконання або неналежне виконання обов'язків і порушення прав, законних інтересів інших учасників, наслідком чого є позбавлення правопорушника певного права або покладення на нього обов'язку.

\section{Jimepamypa}

1. Корпоративне право України : підручник / за заг. ред. В.В. Луця. Київ : Юрінком Інтер, 2010. 384 с.

2. Цивільний кодекс України : закон України від 16.01.2003 р. № 435-IV. Відомості Верховної Ради України. 2003. № 40. Ст. 356.

3. Постанова Пленуму Верховного Суду України від 30.05.2008 р. № 7. URL: http: zakon4.rada.gov.ua/ laws/show/v0007700-08 (дата звернення: 15.12.2020).

4. Гришина I.I. Сутність відповідальності учасників акціонерних правовідносин. Вісник Харківського національного університету внутрішніх справ (збірник наукових праць). 2009. Вип. 45. С. 181-187.

5. Про акціонерні товариства : Закон України від 17.09.2008 р. № 514-VI. Відомості Верховної Ради України. 2008. № 50, 50-51. Ст. 384.

6. Спасибо-Фатеева И. В. Акционерные общества: корпоративные правоотношения. Харьков : Право, 1998. 256 с.

7. Постанова Пленуму Верховного Суду України від 24.10.2008 р. № 13 «Про практику розгляду судами корпоративних спорів». Цивільно-правове регулювання корпоративних відносин у судовій практиці України / упоряд.: В.І. Борисова та ін. Харків : Право, $2013.552 \mathrm{c}$.

8. Теорія держави і права. Академічний курс : підруч. / ред. О.В. Зайчук, Н.М. Оніщенко. Київ : Юрінком Інтер, 2006. 688 с.

\section{Анотація}

Сядриста I. I. Ознаки поняття «акціонерна відповідальність». - Стаття.

У статті розглянуто ознаки відповідальності учасників акціонерних правовідносин. На підставі проведеного аналізу зроблено висновки, що акціонерній відповідальності властиві певні ознаки, які у свою чергу можна поділити на загальні та спеціальні. Акціонерна відповідальність має безпосередній 
зв'язок з акціонерними правовідносинами та може застосовуватися виключно до учасників відповідного правового зв'язку. Підставою застосування цивільно-правової відповідальності до учасників акціонерних правовідносин є невиконання або неналежне виконання обов'язків останніми, що можуть передбачатися законодавством, локальними актами, акціонерним договором, та порушення прав, законних інтересів інших учасників окреслених відносин. Ще однією ознакою відповідальності учасників акціонерних правовідносин є можливість її застосування як у судовому, так і в позасудовому порядку, оскільки акціонерні правовідносини за своєю суттю є внутрішніми, то і відповідальність, що може застосовуватися до їхніх учасників, і порядок її застосування повинні передбачатися не лише на законодавчому, а й на локальному рівні. Порушувати корпоративні права учасників відповідних правовідносин можуть декілька осіб, вони несуть відповідальність як солідарні боржники. Тобто у разі завдання збитків товариству діями (бездіяльністю) його посадових осіб колегіально товариство може звернутися 3 відповідною вимогою до всіх членів органів товариства або до окремого з них. Відповідальність учасників акціонерних правовідносин може застосовуватися лише за ініціативою учасника, чиї права порушено, акціонери не вправі звертатися до суду за захистом прав та інтересів інших акціонерів та самого товариства поза відносинами представництва, а також обгрунтовувати свої вимоги порушенням прав інших акціонерів. Особливістю відповідальності учасників акціонерних правовідносин є те, що підстави іiї застосування, вид і розмір можуть передбачатися не лише нормами законодавства, а й спеціальними локальними актами, такими як статут, акціонерний договір, де можуть бути визначені її межі, види санкцій, підстави звільнення, розподіл ризиків тощо. При цьому підвищена відповідальність може бути встановлена як законом, так і статутом або акціонерним договором, обмежена законом, а статутом та акціонерним договором - якщо цього не забороняє імперативна норма.

Ключові слова: акціонерні правовідносини, акціонерне товариство, акціонери, права, обов'язок, відповідальність.

\section{Summary}

Siadrysta I. I. Signs of the concept of "shareholder liability". - Article.

The article considers the signs of responsibility of the participants of joint-stock legal relations. Based on the analysis, it is concluded that shareholder liability is characterized by certain features, which, in turn, can be divided into general and special. Shareholder liability has a direct connection with the joint-stock legal relationship and can be applied only to the participants of the relevant legal relationship, the basis for civil liability to the participants of the joint-stock legal relationship is non-performance or improper performance of duties by the latter, local acts, shareholder agreement, and violation of the rights, legitimate interests of other participants in the relationship. Another sign of liability of participants in joint-stock legal relations is the possibility of its application both in court and out of court, as joint-stock legal relations are inherently internal, and the liability that may apply to their participants and the procedure for its application should be provided not only legislative, but also at the local level. Several persons may violate the corporate rights of the parties to the respective legal relations, they are liable as joint and several debtors. That is, in case of inflicting losses on the company by actions (inaction) of its officials collegially, the company may apply to all members of the company or to one of them. Liability of participants of joint-stock legal relations can be applied only at the initiative of the participant whose rights have been violated, shareholders may not go to court to protect the rights and interests of other shareholders and the company outside the relationship, as well as justify their claims by violating the rights of other shareholders. The peculiarity of the liability of participants in joint-stock legal relations is that the grounds for its application, type and amount may be provided not only by law but also by special local acts, such as charter, shareholder agreement, which may define its boundaries, sanctions, grounds for dismissal, distribution risks, etc. Thus the increased responsibility can be established both by the law, and the charter or the joint-stock contract, limited by the law, and the charter and the joint-stock contract - if it is not forbidden by the imperative norm.

Key words: joint-stock legal relations, joint-stock company, shareholders, rights, duty, responsibility. 